\title{
The Bank Lending Channel of Monetary Transmission in Turkey
}

\section{Neslihan Turguttopbas ${ }^{\mathrm{a}}$}

Abstract: In this paper, it is aimed to fill a gap in the literature by providing empirical evidence on the influence of monetary policy of Central Bank of Turkey on bank lending in Turkish financial system. In the analysis, the bank level data consisting of 20 banks and monthly market interest rates are used for the period 2001-2017. The findings of the study address three different perspectives of transmission of monetary policy rates. Firstly, the effect of the policy rate on bank lending rates is evaluated and it is confirmed that a change in the policy rate has been reflected in banks' lending rate with 3 months lag. The second group of findings report that the monetary policy affects banks' lending rate in Turkey mainly through its effects on the deposit rates with a lag of 2 months. The third perspective focuses on the balance sheet channel of monetary policy transmission. The results indicate that mainly the policy rate of central bank and liquidity level affect the supply of bank loans. Each of the variables of the adequacy of bank capital and ROA affects the bank's supply of the loans. Amongst the economic variables, the GDP growth has a positive and significant and stock exchange index has negative and significant relation with the supply of bank loans.
Keywords: Monetary Policy, Bank Lending Channel, Balance Sheet Channel

JEL: E52, E58

Received : 11 October 2018

Revised : 28 December 2018

Accepted : 17 January 2019

Type : Research

\section{Introduction}

The possible impetus of the monetary policy on economic growth has been debated for decades theoretically, as well as politically. The politicians, who have been motivated for ensuring the welfare of the population, sometimes even compelled the independent authorities to pay more attention to growth when shaping the monetary policy. There exist some specific questions concerning this debate, the first and the most practically important focus on the contribution of the monetary policy directly to the attainment of a sustainable rate of growth. Apart from this direct affect, the potential of the monetary policy to promote economic growth by maintaining the price stability indirectly is also questioned. Last, but not the least, the time horizon over which the monetary policy effectively influence the pace of growth has also been another point of concern especially to evaluate the effectiveness of the monetary policy measures.

The monetary policy transmission mechanisms are defined as the process by which the monetary policy affects the economy in general. There exist two different approaches when formulating this process which are money and credit views. The money view focuses on the effects of the monetary policy rate changes on aggregate spending in an economy through changes in market interest rates. The money view is empirically supported in economies where the central bank has the ability to affect the short-term nominal interest rate and where there exist elasticity of the investment and consumption expenditures to the changes 
in the real interest rate. In many economies the central banks can influence the term structure of the interest rates, by determining policy interest rate. However, those effects are realized by lags that differ for each economy caused by many peculiar structural factors.

The credit view proposes that in the case of a change in policy rate, the refinancing ability of banks will be affected which is also reflected in the supply of loans by the banks. It incorporates two different explanations from two different perspectives. The balance sheet channel analyzes the affect of the policy rate changes through its affects on the financial positions of the borrowers by means of leverage implications. The second perspective, the bank lending channel, focuses on the changes in the composition of bank balance sheets in response to the monetary policy changes.

Under this theoretical framework of monetary policy transmission mechanisms, both interest rate channel under money view and the bank lending channel under credit view are evaluated in this paper. The data used belongs to Turkish banking system in the period 2001-2017. Referring to the availability of monthly or quarterly data, analysis is made by using 3 different panels of data. Firstly, the affect of the change in the monetary policy rate on bank lending rate, especially whether it is realized in short or medium term, is analyzed. Additionally, a novel approach is modeled with reference to the average funding cost of banks in order to determine the time required for the readjustment of bank lending rate after a policy rate change. Therefore, in this paper, it is aimed to fill a gap in the literature by providing empirical evidence on the influence of monetary policy on bank lending interest rates. Furthermore, it is aimed to provide empirical evidence about the influence of monetary policy on bank behaviors, especially loan supply.

\section{Literature}

The monetary policy exerts an influence on the economy through two transmission mechanisms of money (also known as "interest rate") and credit (also known as "bank lending") channels (Bernanke \& Blinder, 1995). These two views together figures out a combined effect of a change in monetary policy on the market interest rates, as well as on the amount of the loans available to firms. In order to calm down the economy, the central banks generally apply a tightening monetary policy by increasing the policy rate. By that way, the central bank attempts to reduce the investment of firms as cost of capital increases and also available external finance decreases. The magnitude of the effect of the change in monetary policy rate on the markets interest rate and the speed at which the market interest rate reacts to a change in monetary policy are two issues that frequently analyzed literally in order to address the effectiveness of the monetary policy on manipulating the real economy.

The interest rate channel proposes that a decrease in money supply leads to an increase in the real interest rates, referring to the sticky prices assumption of Keynes, which in turn causes the investment and consumer spending to decrease and consequently aggregate demand decreases (Mishkin, 1996). The credit channel transmission focus on the change in the supply of loans by banks as response to a monetary policy shift in the policy rates. The credit channel is analyzed by using two interconnected approach. The "narrow", or as it is traditionally named as bank lending channel (BLC), use the balance sheet as terms of reference and assumes that a tightening in the monetary policy causes an increase in the opportunity cost of holding deposits. Such a reshuffling will result with a relative fall in funding sources of the banks, leading banks to reduce lending (Gambacorta \& Marques-Ibanez, 2011: 8). The "broad" credit channel approach also utilizes balance sheet focus, however expands it to the financial positions of the borrowers that potentially augments real economy fluctuations (Bernanke \& Gertler, 1995).

There exist many studies with respect to the bank lending channel of monetary policy, many of which refer to the paper's of Bernanke and Blinder (1995), Kashyap and Stein (1995), Peek and Rosengren (2013) that address the role of the financial institutions in the transmission of the monetary policy. It is proposed that three conditions should exist for the bank lending channel to operate in an economy, which are; the existence of an incomplete and imperfect credit markets, imperfect substitutability between banking credit and other sources of external funding for some firms and household and the ability of the central bank to affect the supply of bank loans (Gomez-Gonzalez et al., 2016). Despite the fact that all of those conditions 
are met in especially the emerging market economies, many studies focused on US and Europe. Kishan and Opiela (2000) evaluated the existence of the bank lending channel in the US with a differential effect on banks depending on their size and capitalization. Angeloni et al. (2003) used the data of many of the largest euro countries over the period 1993-1999 and suggested that the magnitude of the effects of the change in policy rate on the bank lending has been determined by the level of liquid assets. Their findings were twofold; firstly they showed that banks that hold more liquid assets showed weaker loan adjustment in the wake of changes to the short-term interest rates. Additionally, they indicated that monetary policy does not have a greater impact on the lending of small banks referring to some structural characteristics of European banking system such as the importance of banks' networks, state guarantees and public ownership (Ehrmann et al., 2003; Ehrmann \& Worms, 2004). Gambacorta and Rossi (2010) also analyzed the EU countries and determined that contradictory monetary policy has a greater effect on bank lending, prices and real output than expansionary monetary policy. Another detailed analysis revealed that capital value, liquidity level and magnitude of the banks affect the bank lending channel by using Lerner index to measure market power of the banks. Also, it was stated in the study that the increasing competition boosts the efficiency of monetary policy transmission through bank lending channel in Euro countries (Leroy, 2014).

The bank size and capitalization effects are also determined in China by Xiong (2013). Olivero et al. (2011a, 2011b) who used data for several emerging markets and reported that consolidated financial sectors with lower competition levels are less responsive to monetary policy changes. Ghossoub and Reed (2015) also confirmed the effect of the banking concentration on monetary policy transmission. Saumitra and Toto (2012) used the bank level data and concluded that small, illiquid banks are more responsive to monetary policy changes. Besides, it has been found that public banks are more responsive to monetary policy than foreign banks.

Sengonul and Thorbecke (2005), Erdoğan and Beşballı (2009) and Özşuca and Akbostancı (2013) confirmed the existence of lending channel of monetary transmission in Turkey. Çatık and Karasuca (2011) reported that the interest rate channel is only valid for the post-inflation targeting period and also the effect of monetary shocks on credit volume is very limited especially in the low inflation regime in Turkey. Çiçek (2005) determined that the real production starts to fall sharply after a tightening in the monetary policy, reaching a maximum decline after 2 quarters and there is a fairly long time lag of 1 year to achieve a reduction of prices. Aydın (2006) revealed that corporate loans are not that sensitive to monetary policy rate changes, the long-term pass-through to cash and automobile loans is one-for-one and the elasticity of housing loan rates with respect to the policy rate is greater than unity. Baş̧̧ et al. (2007) also reported that the importance of interest rate and credit channels in Turkey have increased compared to pre-crisis period. A more recent study revealed that monetary policy through the bank lending channel plays an important role on the real economy in the short term (Uslu \& Karahan, 2016).

The link between policy rates and interest rates applied by banks has been another discussion subject literally. The studies published before the financial crisis of 2008-2009 generally considered the policy rate as a reasonable proxy for the cost of short-term funding. Cottarelli and Kourelis (1994) used both market rates and policy rates to determine the short-term dynamics of loan rates by focusing on the structural factors across countries. Karagiannis et al (2010) compare the interactions between money market, policy, and bank rates in Euro area and US. They concluded that in the euro area, short-term market rates have a more pervasive impact on bank rates whereas the policy rate is more influential in the US. By focusing on the unconventional approach by using a multiple policy rate framework within an asymmetric and wide corridor of Central Bank of Turkey (CBT) since end-2010, Binici et al. (2016) determined that the overnight interbank rates, not the policy rate, play a key role in the pricing of loans and deposits,

\section{Economic and Financial Conjuncture}

In Turkish financial system, there exist 33 commercial, 13 development and investment banks and 5 participation banks that operate in line with Islamic rules. Banking sector dominates the Turkish financial sector, accounting for over 70 percent of overall financial services, while insurance services and other financial activities also show significant growth potential. 
As of January 2018, the total assets of Turkey's banking sector increased to 3.2 trillion Turkish liras (\$868.7 billion) with an annual rise of $13.3 \%$. The ratio of asset size to GDP realized as around 1 as of end-2017. The biggest sub-category of assets are consisting of loans and total amount of loans reached a level of 2.1 trillion Turkish liras ( $\$ 564.8$ billion) marking a $17 \%$ yearly increase. Deposits held at the banks amounted to 1.7 trillion Turkish liras (\$459 billion) as of January 2018 , indicating a $14.3 \%$ percent rise on a yearly basis. The banking sector's regulatory capital to risk weighted assets is at $16.78 \%$ up from $15.17 \%$ in the same month of 2017. According to the Banking Watchdog (BDDK) figures, the ratio of non-performing loans to total cash loans, another indicator that shows how healthy the banking sector, is $2.95 \%$ showing an improvement by falling from 3.19\% in the same month of last year. In 2017, Turkish banking sector's net profit hit its all-time high, reaching a level of 49.1 billion Turkish liras (\$13 billion) with a yearly increase of $30.8 \%$.

The 2001 crisis has been a turning point for the Turkish economy and financial markets as it consisted of many features of banking, fiscal, and balance of payment crises. The response was realized in the form of several structural adjustments on the fiscal, monetary and prudential dimensions. The new Central Bank law, introduction of a floating exchange rate regime along with inflation targeting, consolidation and strengthening of the banking system and fiscal balances, and foundation of a new banking regulatory and supervisory agency (BDDK) are amongst the major restructuring efforts. The confidence created by those structural improvements supported by the demographic factors, attracted the ample global liquidity and Turkey faced rapid credit growth during the 2000s.

In order to respond to global financial volatility, CBT has adopted an unconventional approach by using a multiple policy rate framework within an asymmetric and wide corridor since end-2010. The representation of the policy is given in Figure 1. The interbank rates were allowed to deviate from the officially announced policy rates. In the conventional corridor systems money market rate is close to the policy rate, however the CBRT's system exhibits systematically large divergences between interbank rates and policy rates. The CBRT's policy allows the upper and lower bound of the corridor to change at different rates and directions, using the width of the corridor effectively as an additional policy tool. This creates another advantage as compared to the conventional policy framework where the monetary authority adjusts the corridor parameters in the same direction and by a similar magnitude with the main policy rate. Under such an unconventional policy framework, the interest rate channel of the monetary policy transmission mechanism becomes even more interesting and complex, because it is not straightforward which interest rate would the banks take as the benchmark rate for loan and deposit rate setting (Binici et al., 2016: 4).

Figure 1. CBRT Rates and BIST Interbank Market Rates (\%)

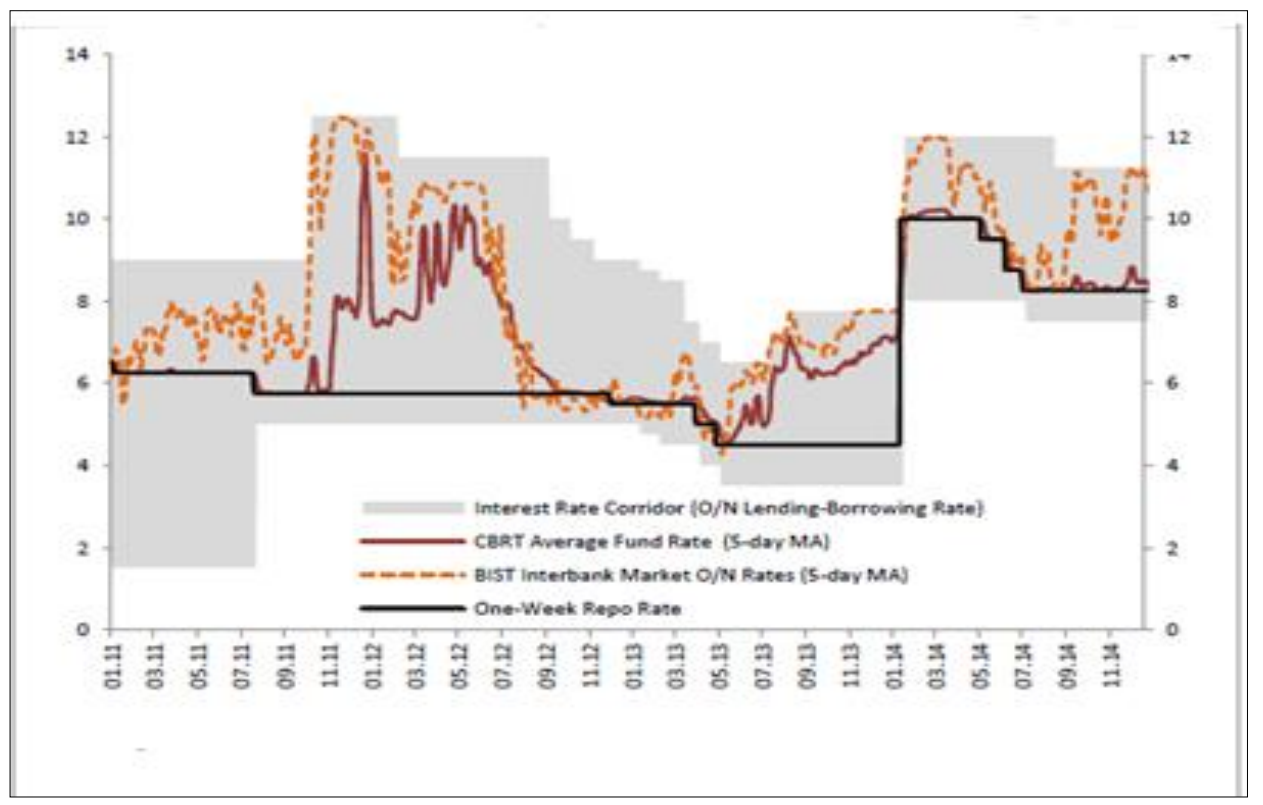




\section{Data and Variables}

There exist three groups of panel data used in the analysis: The first group (Panel A) consists of monthly interest rates grouped under Panel A1 and Panel A2. Panel A1 consist of monthly interest rates for the period May2002-October 2017:

- TLLOANRATE (Change in monthly average interest rates applied by Turkish banking sector to nonfinancial sector loans in Turkish Lira,

- $\mathrm{TCMB} \mathrm{T}_{\mathrm{N}}$ (Change in policy rate of Central Bank of Turkey (CBT) $-\mathrm{N}$ month ${ }^{1}$ ),

- FEDFUNDS (Change in monthly interest rate of US FED Funds),

- $\quad$ TLMEV (Change in monthly average interest rate applied to TL deposits).

Panel A2 consist of monthly interest rates for the period between February 2011 -October 2017 (As some of the below mentioned data are available after February 2011, these interest rates grouped under Panel A2):

- LENDRATE (Change in TL interest rates applied by Turkish banking sector calculated as weighted average interest rate applied to loans in TL to corporate and household sectors),

- BIST (Change in interbank monthly average repo rates in TL in Borsa Istanbul interbank money market (BIST, thereafter in this Paper)),

- CBTRATE (Change in average interest rate of TL funding provided by Central Bank of Turkey to banking sector),

- DEPRATE (Change in Average Interest Rate Applied to Deposits in TL up to 1 year),

- $\mathrm{TCMB}_{\mathrm{N}}$ (Change in policy rate of Central Bank of Turkey (CBT) $-\mathrm{N}$ month).

The second group (Panel B) of data consists of year-end bank level ratios for 20 banks operating in the period 2001-2016. After the banking sector restructuring program applied after 2001 crisis, the structure and regulation of Turkish banking system have changed substantially and this is why 2001 is determined as the starting year for the analysis. The bank level ratios in Panel B are:

- LOANTA (The Ratio of Loans in TL to Total Assets),

- EQUITYTA (The Ratio of Equity to Total Assets),

- DEBTA ((The Ratio of Deposits in TL to Total Assets),

- TLLIQTA (The Ratio of Liquid Assets in TL to Total Assets),

- $\quad$ LLRTA (The Ratio of Loan Loss Reserves to Total Loans),

- INTRATE (The Ratio of Interest Income to Total Loans)

- ROA (Return on Assets),

- MPR (total monthly change in Monetary Policy Rate).

The third groups of variables named as CCONTROL (Panel C) in the regressions are yearly economic indicators including:

- GDP which is GDP growth rate measured as the first difference in the natural logarithm of real GDP.

- LNBSD represents banking sector development which is the ratio of natural logarithm of domestic credit to private sector by banks to GDP.

- MKTRETURN represents stock market return computed as the first difference in the natural logarithm of the stock market index and is a measure of stock market conditions indicating the investors' sentiments about the economy. 
- LNTTRADE is computed as the ratio of the natural logarithm of the sum of imports and exports to the natural logarithm of GDP and it is a proxy for the international trade performance of a country.

Panel $B$ and Panel C consist of yearly data and this can be questioned by econometric perspective, however referring to the findings of Ashcraft (2006) and Gambacorta (2005) who compared the results collected from annual data to those captured from quarterly data of similar samples, annual data is considered to be sufficient to reveal the effects of monetary policy on bank lending.

Table 1 reports summary statistics for the interest rate variables for two periods, bank level variables for 20 banks, as well as economic indicators for the period 2001-2016. The first group of variables indicate that Central Bank of Turkey lowered the policy rate $24 \%$ on average during the period, the response of the banking sector on loan side was realized as $19 \%$ and on deposit side $22 \%$ rate cuts. Panel A2 variables has been figured out by considering the TL funding cost of banks which consist of TL deposit, TL borrowing in interbank market in BIST and TL funding provided by Central Bank of Turkey as addition to their own equity. In the period between February 2011-October 2017, banks increased interest rate applied to loans in TL by $9 \%$ as a response to the increase in interbank TL borrowing rate by $7.2 \%$, in CBT funding rate by $7.8 \%$ and the interest rate of TL deposit by $6.5 \%$. Those findings show that, on average, banks are more responsive to make changes in interest rates applied to deposits than to loans in TL.

Referring to the bank level variables (Panel B) reported in Table 1, it can be concluded that for the period 2001-2016, loans in TL represent $34.1 \%$ of total assets of banks. On average $28.6 \%$ of total assets are funded by deposits up to 1 years and $15.7 \%$ by equity. $18 \%$ of total assets consist of liquid assets in TL and the average loan loss rate is $1.8 \%$ of total assets. Banks generate $43.5 \%$ of loans in TL as interest income on average and their average Return on Assets is $1.4 \%$. In this period, CBT lowered the policy rate $3.1 \%$ on average.

Table 1. Descriptive Statistics

\begin{tabular}{|c|c|c|c|c|}
\hline All in \% & Mean & Std.Dev & ADF & t- \\
\hline \multicolumn{5}{|c|}{ Panel A: Monthly Interest Rates for the period February 2002-October 2017} \\
\hline TLLOANRATE & -0.19 & 1.08 & -12.018 & \\
\hline TCMB T1 & -0.24 & 1.22 & -10.766 & \\
\hline FEDFUNDS & 0.00 & 0.14 & -5.971 & \\
\hline TLMEV & -0.22 & 0.79 & -9.693 & \\
\hline \multicolumn{5}{|c|}{ Panel A2: Monthly Interest Rates for the period February 2011 - October 2017} \\
\hline LENDRATE & 0.09 & 0.60 & -5.294 & \\
\hline BIST T1 & 0.072 & 0.813 & -6.545 & \\
\hline TCMB & 0.078 & 0.711 & -8.393 & \\
\hline CBTRATE & 0.065 & 0.569 & -6.821 & \\
\hline TCMB T1 & 0.009 & 0.784 & -9.321 & \\
\hline
\end{tabular}

Panel B. Yearly Bank Level Variables for The Period 2001-2016

\begin{tabular}{|c|c|c|c|c|c|}
\hline \multirow[b]{2}{*}{ All in \% } & \multirow{2}{*}{ Mean } & \multirow{2}{*}{ Std.Dev } & \multicolumn{3}{|c|}{ Unit Root Statistics } \\
\hline & & & Data & First Diff. & \\
\hline LOANTA & 0.341 & 0.162 & -6.3745 & -5.5168 & \\
\hline EQUITYTA & 0.157 & 0.153 & -3.2578 & -6.4256 & \\
\hline DEBTA & 0.286 & 0.181 & 3.983 & 12.1217 & $*$ \\
\hline TLLIQTA & 0.17 & 0.10 & $-1.815 *$ & -8.86 & \\
\hline LLRTA & 0.018 & 0.017 & -9.1192 & -13.2647 & \\
\hline INTRATE & 0.435 & 1.236 & -9.522 & -18.362 & \\
\hline ROA & 0.014 & 0.031 & $10.013 *$ & -1.882 & * \\
\hline MPR & -0.0314 & 0.07 & -15.1187 & 1.5927 & * \\
\hline
\end{tabular}


N. Turguttopbas

Panel C. Yearly economic indicators for the period 2001-2016

\begin{tabular}{|l|l|l|l|c|}
\hline \multirow{2}{*}{ All in \% } & \multirow{2}{*}{ Mean } & \multirow{2}{*}{ Std.Dev } & \multicolumn{2}{|c|}{ UnitRootStatistics } \\
\cline { 4 - 5 } & & & Data & First Diff. \\
\hline GDP & 0.077 & 0.052 & -6.8822 & -6.6166 \\
LNBSD & 0.16 & 0.272 & -4.7604 & -14.0321 \\
MRKTRET & 0.113 & 0.229 & -5.3463 & -8.3441 \\
LNTRADE & 1.387 & 0.015 & 4.8021 & $*$ \\
\hline
\end{tabular}

* Denotes significance at the $5 \%$ level.

The Augmented Dickey-Fuller (ADF) test results for time series data of Panel A1 and Panel A2 are given in Table 1, the results of this ADF test show that the null hypothesis of unit root is rejected for each variable. For the panel data given in Panel B, Levin-Lin-Chu Test (2002) suggesting the null hypothesis that all the panels contain a unit root with the specifications of 1 lag ADF regressions, Bartlett kernel and 7 lags average are performed. All test results except DEBTA, TLLIQTA, ROA and LNTRADE indicated the rejection of the hypothesis. In the second stage, the first differences of the data have been tested only ROA data seems to have unit root.

Table 2. Correlation Coefficients

\begin{tabular}{|c|c|c|c|c|c|c|c|c|c|c|c|c|c|c|c|}
\hline & LOANTA & & EQUITYTA & DEBTA & TLLIQTA & & LLRTA & INTRATE & & ROA & MPR & GDP & LNBSD & MRKTRET & LNTRADE \\
\hline LOANTA & 1 & & & & & & & & & & & & & & \\
\hline EQUITYTA & $-0,1234$ & & 1 & & & & & & & & & & & & \\
\hline DEBTA & 0,4270 & $*$ & $-0,3477 *$ & 1 & & & & & & & & & & & \\
\hline TLLIQTA & $-0,2287$ & $*$ & 0,1279 & 0,0717 & 1 & & & & & & & & & & \\
\hline LLRTA & $-0,0789$ & & $0,2512 *$ & 0,0191 & 0,0395 & & 1 & & & & & & & & \\
\hline INTRATE & $-0,0859$ & & $-0,0702$ & $0,2168 *$ & 0,1186 & & 0,1469 & 1 & & & & & & & \\
\hline ROA & 0,0445 & & 0,1061 & $-0,1263$ & 0,0885 & & $-0,2112$ & $-0,1140$ & & 1 & & & & & \\
\hline MPR & 0,3554 & * & 0,0230 & $0,2177^{*}$ & 0,0769 & & $-0,0799$ & $-0,0768$ & & $-0,0698$ & 1 & & & & \\
\hline GDP & 0,1005 & & 0,0196 & $-0,0730$ & 0,1156 & & $-0,1766$ & $-0,2725$ & $*$ & 0,3199 & $* \quad 0,1378$ & 1 & & & \\
\hline LNBSD & $-0,0877$ & & 0,0782 & $-0,1663 *$ & 0,2223 & $*$ & $-0,0643$ & $-0,2957$ & $*$ & 0,3988 & * $\quad-0,0025$ & $0,5499 *$ & 1 & & \\
\hline MRKTRET & $-0,0907$ & & 0,0558 & $-0,1455$ & 0,1817 & $*$ & $-0,0620$ & $-0,2270$ & * & 0,3158 & * $\quad 0,0989$ & $0,6487 *$ & $0,7907 *$ & 1 & \\
\hline LNTRADE & 0,0209 & & 0,1026 & $-0,0430$ & 0,2757 & $*$ & $-0,0594$ & $-0,2258$ & * & 0,3647 & 0,0331 & $0,5521 *$ & $0,6418 *$ & $0,3987 *$ & 1 \\
\hline
\end{tabular}

$*$ denotes signifisance at the $1 \%$ level

Table 2 reports the correlation coefficients for bank-level variables, as well as economic indicators. The correlation coefficients between explanatory variables are mostly statistically significant at even $1 \%$ significance level. They are mostly less than 0.45 except the correlation coefficients between economic indicators of the growth in the natural logarithm of GDP and the growth in natural logarithm of the domestic credit to private sector by banks. This can signal the removal of one of them from the regression(s) because of multicollinearity. Table 2 reports two unexpected relations; the loan to asset ratio (LOANTA) has positive and statistically significant relation with the policy rate of CBT (MPR) and has a negative but not significant relation with the lending rate of banks (INTRATE). This finding can address the existence of lagging relations between loan amounts and both interest rate variables.

\section{Models and Empirical Results}

\subsection{The Effect of Monetary Policy on Interest Rates}

In order to analyze the power of monetary policy rate to affect the bank lending rate to shape the economic activity as targeted, the hypothesis is specified as "The change in policy interest rate is positively associated with a change in banks' lending rate, at short horizons". This has been also the flag argument of 
the money channel of transmission mechanism and has been tested in many different countries. The short term response of the interest rate environment has been critical in order to create desired shifts by the policy changes. In order to test the stated hypothesis in Turkish financial markets, both deterministic approach of Brämer et al. (2013) and the contributions of Vithessonthi et al. (2017) to their analysis are used in this analysis.

The model proposed by Vithessonthi and friends (2017), uses the first difference in monthly average interest rates applied by Turkish banking sector to non-financial sector in TL as the dependent variable ( TLLOANRATE $_{t}$ ) and the first difference in policy rate (TCMB) and US FED Funds rate (FEDFUNDS ${ }_{t}$ ) as independent variables. In order to determine possible lagging effect of the policy rate changes on the TL lending rate, laggings values of the first differences in policy rate (TCMB) up to 3 months have also been included in the model. In order to figure out the "short-term" effects of the policy rate change on bank's lending rate at most 3 months has been considered to be the most appropriate horizon. The following regression equation has been tested by using the monthly data in the period June 2002 - October 2017.

$$
\Delta T_{L L O A N R A T E}=a_{0}+\alpha_{1} \Delta F E D F U N D S_{t}+\Delta T C M B_{t}+\Delta T C M B_{t-1}+\Delta T C M B_{t-2}+\Delta T C M B_{t-3}+\varepsilon
$$

Table 3 reports the results of OLS (Ordinary Least Squares) and GLM (Generalized Linear Model) regressions with the change in the bank's lending rate as the dependent variable and the change in the US policy interest rate as control variable and the change in the policy interest rate and its three lags as the explanatory variables. The results of the OLS regressions with robust standard errors and GLM regressions with Huber/White robust standard errors by using monthly interest rates for the period between February 2002 - October 2017 are reported in Table 3. In order to detect multicollinearity of the variables, the variance inflation factors (VIF) are reported in the table and as they are less than 10, it can be said that there exist no multicollinearity problem.

Table 3. OLS and GLM Regressions Results

\begin{tabular}{|c|c|c|c|}
\hline & OLS & GLM & VIF \\
\hline \multirow[t]{2}{*}{ Constant } & -0.049 & -0.049 & 1.08 \\
\hline & -0.57 & -0.57 & \\
\hline \multirow[t]{2}{*}{$\triangle \mathrm{TCMB}$ T1 } & -0.671 & -0.067 & 2.69 \\
\hline & -0.24 & -1.73 & \\
\hline \multirow[t]{2}{*}{$\triangle \mathrm{TCMB}$ T2 } & -0.073 & -0.073 & 6.74 \\
\hline & -0.34 & -0.7 & \\
\hline \multirow[t]{2}{*}{$\triangle \mathrm{TCMB} T 3$} & 0.245 & 0.245 & 4.92 \\
\hline & 3.5 & 11.09 & \\
\hline \multirow[t]{2}{*}{$\triangle$ FEDFUNDS } & -0.685 & -0.686 & 1.01 \\
\hline & -0.96 & -1.83 & \\
\hline Adjusted R2 & 0.2099 & & \\
\hline F-statistic & 6.64 & & \\
\hline LR-statistic & & -240.055 & \\
\hline Observations & 184 & & \\
\hline
\end{tabular}

The noteworthy finding of the results given in Table 3 is the positive and significant relation between banks' lending rate and policy rate of CBT with 3 months lag. This means that a change in the policy rate has been reflected in banks' lending rate after 3 months. The robustness of the findings is tested by using Vector Autoregressions (VAR) with endogenous variables of $\triangle T L_{L}$ ANNRATE $_{t}, \triangle T C M B_{T}$ and $\triangle F E D F U N D S$ with four lags. The calculated Akaike information criterion, Schwarz information and Hannan-Quinn information criterion are $2.638 ; 2.762$ and 2.688 respectively. Consistent with the regression results, it can be suggested that the monetary policy affects banks' lending rate in Turkey in the short-run (within three months). This finding supports the findings of Vithessonthi et al. (2017) who determined that after controlling for the US monetary policy, the monetary policy in Germany and Thailand appears to influence banks' lending rate in the short- 
run (i.e. within two months), but not in Switzerland. They attributed the results to the fact that high degree of capital mobility in Switzerland that results with the domestic market interest to be more aligned with global interest rate.

\subsection{Cost of Funding Approach}

It is an operational fact that the lending rates by banks are determined by taking into consideration their average cost of funding. In this framework, Turkish banks fund loans in TL are financed by mainly deposits in TL, interbank borrowings through repo transactions in TL and financing provided by Central Bank of Turkey to banks in TL. This means that monetary policy rate affect the lending rate of banks by interacting the deposit and interbank interest rates and this readjustment takes some time. The above finding of 3 months lag for changing the lending rates of banks after a change in policy rate of CBT can be attributed to this readjustment of average cost of TL funding. In this regard, an empirically novel approach can be figured out as the following regression equation which takes into account changes in the interest rates for each source of funds in TL, as well policy rate of CBT:

$$
\begin{aligned}
& \Delta \text { LENDRATE }_{\mathrm{t}}=\Delta \text { DEPRATE }_{t}+\Delta \text { BIST }_{\mathrm{t}}+\Delta \text { CBTRATE }_{\mathrm{t}}+\Delta \text { TCMB }_{t}+\Delta \text { TCMB }_{t-1} \\
& +\triangle \text { TCM }_{t-2}+\Delta \text { TCMB }_{t-3}+\varepsilon
\end{aligned}
$$

In the equation (2), LENDRATE represents the first difference in TL interest rates applied by Turkish banking sector to the non-financial sector, DEPRATE represents the first difference in average interest rate applied to deposits in TL up to 1 year, BIST represents change in interbank monthly average repo rates in TL, CBTRATE represents the first difference in average interest rate of TL funding provided by Central Bank of Turkey to banking sector and TCMB represents the first difference in policy rate of CBT. In order to determine possible lagging effect of policy rate changes on the TL lending rate, laggings values of the first differences in policy rate (TCMB) up to 3 months have also been included in the model. The results of the OLS regressions with robust standard errors and GLM regressions with Huber/White robust standard errors by using monthly interest rates for the period February 2011 - October 2017 are reported in Table 4. In order to detect multicollinearity of the variables, the variance inflation factors (VIF) are reported in the table and as they are less than 10 , it can be said that there exist no multicollinearity problem.

\begin{tabular}{|c|c|c|c|}
\hline & OLS & GLM & VIF \\
\hline \multirow{2}{*}{ Constant } & 0.077 & 0.077 & 1.03 \\
\hline & 1.47 & 1.58 & \\
\hline \multirow[t]{2}{*}{$\triangle \mathrm{TCMB}$ T1 } & -0.137 & -0.137 & 2.2 \\
\hline & -0.98 & -1.5 & \\
\hline \multirow[t]{2}{*}{$\triangle T C M B$ T2 } & 0.258 & 0.258 & 4.09 \\
\hline & 3.08 & 2.84 & \\
\hline \multirow[t]{2}{*}{$\triangle \mathrm{TCMB}$ T3 } & 0.131 & 0.131 & 3.29 \\
\hline & 1.81 & 1.99 & \\
\hline \multirow[t]{2}{*}{$\triangle$ DEPRATE } & 0.238 & 0.238 & 1.49 \\
\hline & 2.01 & 2.3 & \\
\hline \multirow[t]{2}{*}{$\triangle B I S T$} & 0.001 & 0 & 1.85 \\
\hline & 0 & 0 & \\
\hline \multirow[t]{2}{*}{$\triangle$ CBTRATE } & -0.086 & -0.086 & 1.56 \\
\hline & -0.73 & -1.02 & \\
\hline Adjusted R2 & 0.4978 & & \\
\hline F-statistic & 15.36 & & \\
\hline LR-statistic & & -46.005 & \\
\hline Observations & 83 & & \\
\hline
\end{tabular}

Table 4. OLS and GLM Regressions Results 
The results given in Table 4 support the findings of monetary transmission approach, the monetary policy rate changes affect banks' lending rate in Turkey by mainly through its effects on the deposit rates. When the components of TL cost of funding are determined as dependent variable, the statistically significant positive coefficient of $\triangle T C M B T_{2}$ addresses that the change in banks' lending rate is realized after 2 months after the policy rate change of CBT. Not surprisingly, the average deposit interest rate has positive and statistically significant relation with banks' lending rate. The robustness of the findings is tested by using

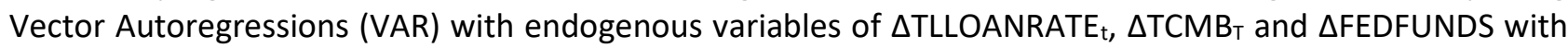
four lags. The calculated Akaike information criterion, Schwarz information and Hannan-Quinn information criterion are $1.323,1.653$ and 1.455 respectively. Consistent with the regression results, it can be suggested that the monetary policy affects banks' lending rate in Turkey mainly through its effects on the deposit rates and the length of the lag is 2 months.

\subsection{The Effect of Interest Rates on Supply of Bank Loans}

The affect of monetary policy rate on the supply of bank loans has been another investigated issue in many economies by the researchers. The hypothesis predicts that the response of supply of banks' loans to the growth opportunities has negative relation with the magnitude of the lending rate. This means that the bank level characteristics, as well as economic indicators including the monetary policy rate potentially affect the supply of bank loans. To test the hypothesis, the following regression is used in which total loans to total assets ratio $\left(\right.$ LOANTA $\left._{t}\right)$ is set as dependent variable and BCONTROL $\mathrm{L}_{i, t-1}$ which is a vector of bank-level control variables for bank $i$ at time $\mathrm{t}-1$ and $\mathrm{CCONTROL}_{\mathrm{t}-1}$ which is a vector of country level control variables at time $t-1$ are set as independent variables. The bank level consists of year-end financial panel data for 20 Turkish banks in the period 2001-2016:

$$
\operatorname{LOANTA}_{i, t}=\propto+\beta_{1} \text { BCONTROL }_{i, t-1}+\delta \text { CCONTROL }_{t-1}+\operatorname{INTRATE}_{T-1}+\varepsilon_{i, t}
$$

A series of balanced panel OLS regressions for the Equation3 using (1) bank-fixed effects, (2) bankfixed effects and period-fixed effects, and (3) without fixed effects are estimated. Table 5 presents the estimation results of the unbalanced panel OLS regressions of the loan ratio (LOANTA), which is computed as total loans scaled by total assets, on the lending rate (INTRATE). INTRATE is computed as the ratio of total interest income to total loans for each bank, for a sample of 20 banks operating in Turkey in the period 20012016.

In column 1, the estimations of the base regressions by regressing the loan ratio (LOANTA) on bankand country-level control variables only (without bank-fixed, country-fixed, and period-fixed effects) reports the adjusted $R^{2}$ as $36.31 \%$. The next Column (2) reports an increase in $R^{2}$ to $65.97 \%$ when country fixed effects are included in the baseline regression. In Column 3, both the bank- and country-level fixed effects estimates a $\mathrm{R}^{2}$ of $75.36 \%$ which means that the bank- and country-level control variables can explain substantial variation in the loan ratio.

For all of the three panel OLS regressions with different fixed effect considerations, monetary policy rate (MPR) has positive and the ratio of Liquid assets in TL to Total Assets (TLLIQTA), has negative effects on bank loans and both are statistically significant. When no fixed effects are figured out, the deposit-to-asset ratio (DEPTA) and operating performance (ROA) are significantly associated with bank loans. With only bank fixed effects, two bank-level factors which are the equity ratio (EQUITYTA) and operating performance (ROA) have significant association with bank loans. These findings are generally in line with the findings of Vithessonthi et al. (2017).

With bank-fixed effects and period-fixed effects, two bank-level control variables which are the equity ratio (EQUITYTA) and INTRATE are determined to have positive relationship with loan ratio. The latter effect is controversial to the finding of Vithessonthi et al. (2017) who found negative and significant effect of INTRATE on bank loans. This can be explained by the high dependence of banking sector financing in Turkey in tough times when lending rates are increasing. The results indicate that monetary policy rate and liquidity 
level of the bank affects the supply of bank loans in three of the models. Each of the variables of adequacy of the bank capital and ROA affects the bank's supply of the loans in two models out of three.

Amongst the economic variables, the increase in natural logarithm of GDP has a positive and significant relationship for all of the three models in line with the expectations. This means that the economic growth makes people and corporate to spend and invest more by using loans from banks. There also exist negative and significant relation between the change in the natural logarithm of the stock exchange index MRKTRET and the supply of bank loans. This can be explained by the lagging reflections of the stock market against the financial distress caused by the amortizations of intensive borrowings of the corporate in the following years.

Table 5. OLS and GLM Regressions Results

\begin{tabular}{|c|c|c|c|}
\hline LOANTA & (1) & (2) & (3) \\
\hline \multirow[t]{2}{*}{ INTRATE $_{\mathrm{t}-1}$} & -0.012 & 0.012 & $0.016^{*}$ \\
\hline & -1.87 & 0.24 & 3.11 \\
\hline \multirow[t]{2}{*}{ EQUITYTA } & 0.041 & 0.219 & $0.2^{*}$ \\
\hline & 0.74 & 4.59 & 4.66 \\
\hline \multirow[t]{2}{*}{ DEBTA } & 0.38 & 0.008 & 0.011 \\
\hline & 7.94 & 0.1 & 0.15 \\
\hline \multirow[t]{2}{*}{ TLLIQTA } & -0.457 & -0.25 & -0.188 \\
\hline & -5.47 & -2.71 & -2.26 \\
\hline \multirow[t]{2}{*}{ LLRTA } & -0.032 & 0.304 & 0.673 \\
\hline & -0.06 & 0.64 & 1.57 \\
\hline \multirow[t]{2}{*}{ ROA } & 0.644 & 0.771 & 0.255 \\
\hline & 2.32 & 3.66 & 1.27 \\
\hline \multirow[t]{2}{*}{ MPR } & 0.648 & 0.857 & $0.543^{*}$ \\
\hline & 5.67 & 9.16 & 5.85 \\
\hline \multirow[t]{2}{*}{ GDP } & 0.553 & 0.723 & $0.211^{*}$ \\
\hline & 2.48 & 4.35 & 3.3 \\
\hline \multirow[t]{2}{*}{ LNBSD } & 0.02 & 0.002 & 0.088 \\
\hline & 0.34 & 0.05 & -2.16 \\
\hline \multirow[t]{2}{*}{ MRKTRET } & -0.15 & -0.207 & $-0.062^{*}$ \\
\hline & -2.27 & -4.22 & -1.31 \\
\hline \multirow[t]{2}{*}{ LNTRADE } & 0.001 & -0.367 & 2.04 \\
\hline & 0 & -0.62 & 3.35 \\
\hline \multirow[t]{2}{*}{ Constant } & 0.29 & 0.811 & $-2.417^{*}$ \\
\hline & 0.788 & 1.01 & -7.71 \\
\hline Bank Fixed effects & No & Yes & Yes \\
\hline Period fixed effects & No & No & Yes \\
\hline Adjusted $R^{2}$ & 0.3631 & 0.6597 & 0.7536 \\
\hline F-statistics & 16.49 & 20.32 & 26.44 \\
\hline
\end{tabular}

* Denotes significance at the $5 \%$ level.

\section{Conclusion}

There are two accepted and generally contradicting principles with regards to the emerging market countries. Firstly, they should build an economic environment of sustainable growth. Secondly, they should control the inflation, as well as keep the central bank independence. By that way, they are able to create institutional confidence and gain the power to coordinate the financial markets. In fact this summarizes the situation in Turkey for at least five years. While the central Bank of Turkey strives to keep its independence especially in determining the monetary policy rate and focus on the critical mission of inflation control, the 
authorities urges them to lower the policy interest rate that directly and indirectly affect the market rates downside. Such a drop of market rates will be reflected in the loan interest rates to non-financial sector and by that way both the spending and investments are supposed to increase creating a bright economic environment.

In fact, the relationship between the monetary policy rate and economical and financial fundamentals has been a popular topic for decades. The results of such analysis mostly confirm the existence of monetary policy transmission mechanisms, which is operated through many different channels. Under such a theoretical framework of monetary policy transmission mechanisms, both interest rate channel under money view and the bank lending channel under credit view are evaluated in this paper. It is aimed to fill a gap in the literature by providing empirical evidence on the influence of monetary policy on bank lending interest rates in Turkish financial system. The data used belongs to Turkish financial system which is dominated by banks in the period 2001-2017. Furthermore, it is aimed to provide empirical evidence about the influence of monetary policy on bank behaviors, especially supply of loans. The findings of the study address three different perspectives of transmission of monetary policy rates. Firstly, the effect of the policy rate of Central Bank of Turkey on bank lending rates is evaluated and it is confirmed that a change in the policy rate has been reflected in banks' lending rate with 3 months lag. The second perspective takes into account typical cost of domestic currency funding of Turkish banks. Referring to the fact that Turkish banks fund loans in TL by mainly deposits in TL, interbank borrowings through repo transactions in TL and financing provided by Central Bank of Turkey, this novel approach proposes that monetary policy rate affect the lending rate of banks by interacting the deposit and interbank interest rates and this readjustment takes some time. The empirical findings reports that the monetary policy affects banks' lending rate in Turkey mainly through its effects on the deposit rates. Such a response is generated after a lag of 2 months. The third perspective focuses on the balance sheet channel of monetary policy transmission and predicts that the bank level characteristics, as well as economic indicators including the monetary policy rate potentially affect the supply of bank loans. Three different models have been figured out to address the bank level, bank and period level fixed affects and no fixed affects. The results indicate that monetary policy rate and liquidity level of the bank affects the supply of bank loans in three of the models. Each of the variables of adequacy of the bank capital and ROA affects the bank's supply of the loans in two models out of three. Amongst the economic variables, the GDP growth has a positive and significant and stock exchange index has negative and significant relation with the supply of banks loans.

The analysis in this study is based on the specific corridor system implemented by CBT and this policy end up with different policy and market rates. The findings can be employed by the policy makers of some countries who face divergence between policy rates and market rates. Referring to the fact that FED has applied a target range for the federal funds rate instead of a single policy rate since 2009, short term market rates has differed from policy rate in US similarly. A similar situation has experienced in the policies of ECB after the adoption of quantitative easing policies. It is a fact that the level as well as the divergence of policy and market rates is minisical as compared to Turkish system, this divergence makes the power of policy rate questionable in many countries.

\section{End Notes}

1. Although the policy rate is overnight, the monthly change in those rate are used.

\section{References}

Angeloni, I., Kashyap, A. K., Mojon, B., \& Terlizzese, D. (2003). Monetary transmission in the Euro Area: Where do we stand? In I. Angeloni, A. K. Kashyap and B. Mojon (eds.) Monetary Policy Transmission in the Euro Area Cambridge: Cambridge University Press, 383- 412.

Ashcraft, A. (2006). New evidence on the lending channel. Journal of Money Credit Banking, 38, 751-776. 
Aydın, H. (2007). Interest rate pass-through in Turkey. Central Bank of the Republic of Turkey, Working Paper, No. 07/05.

Başçı, E., Özel, Ö., \& Sarıkaya, Ç. (2007). The monetary transmission mechanism in Turkey: New developments. Central Bank of the Republic of Turkey, Working Paper, No. 07/04.

Bernanke, B. S., \& Gertler, M. (1995). Inside the black box: The credit channel of monetary policy transmission. Journal of Economic Perspectives, 9(1), 27-48.

Binici, M., Kara, H., \& Özlü, P. (2016). Unconventional interest rate corridor and the monetary transmission: Evidence from Turkey. Central Bank of the Republic of Turkey, Working Paper, No. 16/08.

Brämer, P., Gischer, H., Richter, T., \& Weiß, M. (2013). Competition in banks' lending business and its interference with ECB monetary policy. Journal of International Financial Markets, Institutions \& Money, 25, 144-162.

Catik, A. N., \& Karaçuka, M. (2011). The bank lending channel in Turkey: Has it changed after the low inflation regime. Düsseldorf Institute for Competition Economics (DICE) Discussion Paper.

Cottarelli, C., \& Kourelis, A. (1994). Financial structure, bank lending rates, and the transmission mechanism of monetary policy. IMF Staff Papers, 41, 587-623.

Çiçek, M. (2005). Türkiye'de parasal aktarım mekanizması: VAR yaklaşımıyla bir analiz. iktisat, Işsletme ve Finans, 233, 82-105.

Ehrmann, M., Gambacorta, L., Martinez Pagés, J., Sevestre, P., \& Worms, A. (2003). Financial systems and the role of banks in monetary policy. In I. Angeloni, A.K. Kashyap \& B. Mojon (eds.), Monetary Policy Transmission in the Euro Area, Cambridge University Press, Cambridge.

Ehrmann, M., \& Worms, A. (2004). Bank networks and monetary policy transmission. Journal of the European Economic Association, 2(6), 1148-1171.

Erdoğan, S., \& Beşballı, S. G. (2011). Türkiye'de banka kredileri kanalının işleyişi üzerine ampirik bir analiz. Doğuş Üniversitesi Dergisi, 11, 28-41.

Gambacorta, L. (2005). Inside the bank lending channel. European Economic Review, 49(7), 1737-1759.

Gambacorta, L., \& Marques-Ibanez, D. (2011). The bank lending channel lessons from the crisis. European Central Bank Working Paper, No: 1335.

Gambacorta, L., \& Rossi, C. (2010). Modelling bank lending in the euro area: A nonlinear approach. Applied Financial Economics, 20, 1099-1112.

Ghossoub, E. A., \& Reed, R. R. (2015). The size distribution of the banking sector and the effects of monetary policy. European Economic Review, 75, 156-176.

Gomez-González, J., Ojeda-Joya, J., Franco, J., \& Torres, J. (2016). Asset-price bubbles, existence, persistence and migration. South African Journal of Economics, In Press, doi: 10.1111/saje.12108.

Karagiannis, S., Panagopoulos, Y., \& Prodromos, V. (2010). Interest rate pass-through in Europe and the US: Monetary policy after the financial crisis. Journal of Policy Modeling, 32, 323-338.

Kashyap, A. K., \& Stein, J. C. (1995. The impact of monetary policy on bank balance sheets. Carnegie-Rochester Conference Series on Public Policy, Elsevier, 42(1), pp.151-195.

Kishan, R. P., \& Opiela, T. (2000). Bank size, bank capital, and the bank lending channel. Journal of Money, Credit and Banking, 32(1), 121-141.

Levin A, Lin, C. F., \& Chu, C. J. (2002). Unit root tests in panel data: Asymptotic and finite sample properties. Journal of Econometrics, 108, 1-24.

Mishkin, F. (1996). The channels of monetary transmission: Lessons for monetary policy. NBER Working Paper, No. 5464.

Olivero, M., Li, Y., \& Jeon, B. N. (2011a). Competition in banking and the lending channel: Evidence from banklevel data in Asia and Latin America. Journal of Banking and Finance, 35, 560-571.

Olivero, M., Li, Y., \& Jeon, B. N. (2011). Consolidation in banking and the lending channel of monetary transmission: Evidence from Asia and Latin America. Journal of International Money and Finance, 30, $1034-1054$.

Özşuca, E. A., \& Akbostancı, E. (2012). An empirical analysis of the bank lending channel in Turkey. Iktisat, Işletme ve Finans, 28(328), 33- 50.

Peek, J., \& Rosengren, E. S. (2013). The role of banks in the transmission of monetary policy. Federal Reserve Bank of Boston. Public Policy Discussion Paper, No: 13-5. 
Sengonula, A., \& Thorbecke, W. (2005). The effect of monetary policy on bank lending in Turkey. Applied Financial Economics, 15, 931-934

Xiong, Q. (2013).The role of the bank lending channel and impacts on stricter capital requirements on the Chinese banking industry. BOFIT Discussion Papers, No. 7.

Uslu, N., \& Karahan, P. (2016). An analysis on the efficiency of bank lending channel in Turkey. Journal of Business, Economics and Finance, 5(2), 206-217.

Vithessonthi, C., Schwaninger, M., \& Müller, O. M. (2017). Monetary policy, bank lending and corporate investment. International Review of Financial Analysis, 50, 129-142. 